\title{
Bicentenario y Centenario en la UAA
}

\section{Jesús Martínez Ruiz Velasco}

T $\mathrm{n}$ el marco de los festejos por el Bicentenario del ini-

E cio de la Independencia Nacional y el Centenario del inicio de la Revolución Mexicana, la Universidad Autónoma de Aguascalientes (UAA) ha desarrollado una serie de eventos y actividades entre las que se encuentran:

La formación de una bandera humana en el nuevo Estadio Universitario, conformada por aproximadamente 3,000 integrantes de la comunidad universitaria.

La inauguración de la Plaza Cívica Universitaria, la cual se encuentra dedicada a la memoria de los Niños Héroes de Chapultepec y del Heroico Colegio Militar. En esta área se construyó un Asta Bandera Monumental con apoyo de la Secretaría de la Defensa Nacional y de la XIV Zona Militar de Aguascalientes.

La exposición "Camino al Bicentenario 1810-2010", que muestra una serie de imágenes relacionadas con la Independencia y la Revolución a través de 21 mamparas y dos torres ubicadas en una parte del perímetro de Ciudad Universitaria.

Realización de diversas actividades como: ciclos de cine, conciertos, publicaciones, conferencias, entre otras; todas las cuales se encuentran relacionadas con las etapas y momentos históricos celebrados.

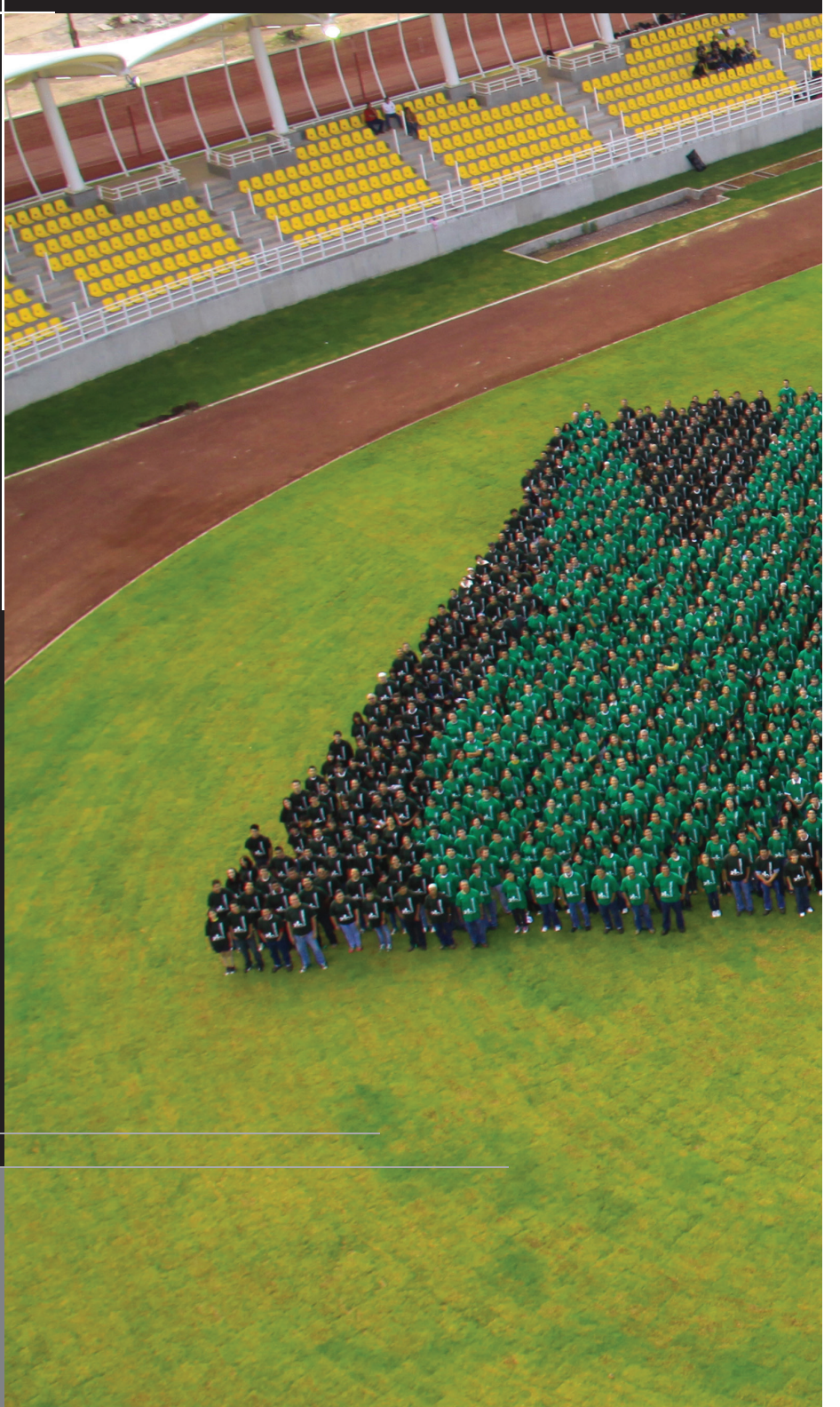

\section{Fuente de consulta}

UAA, Boletines núm. 290, 316, 318 y 327, México, UAA, Departamento de Comunicación y Relaciones Públicas, 2010. Recuperados el 22 de septiembre de 2010 en http://www.uaa.mx 


\section{0}

\section{UNIUERSIDaD aUTOnoma} DE aguascalientes

Conmemoración del Bicentenario del inicio de la Independencia de México y del Centenario de la Revolución Mexicana
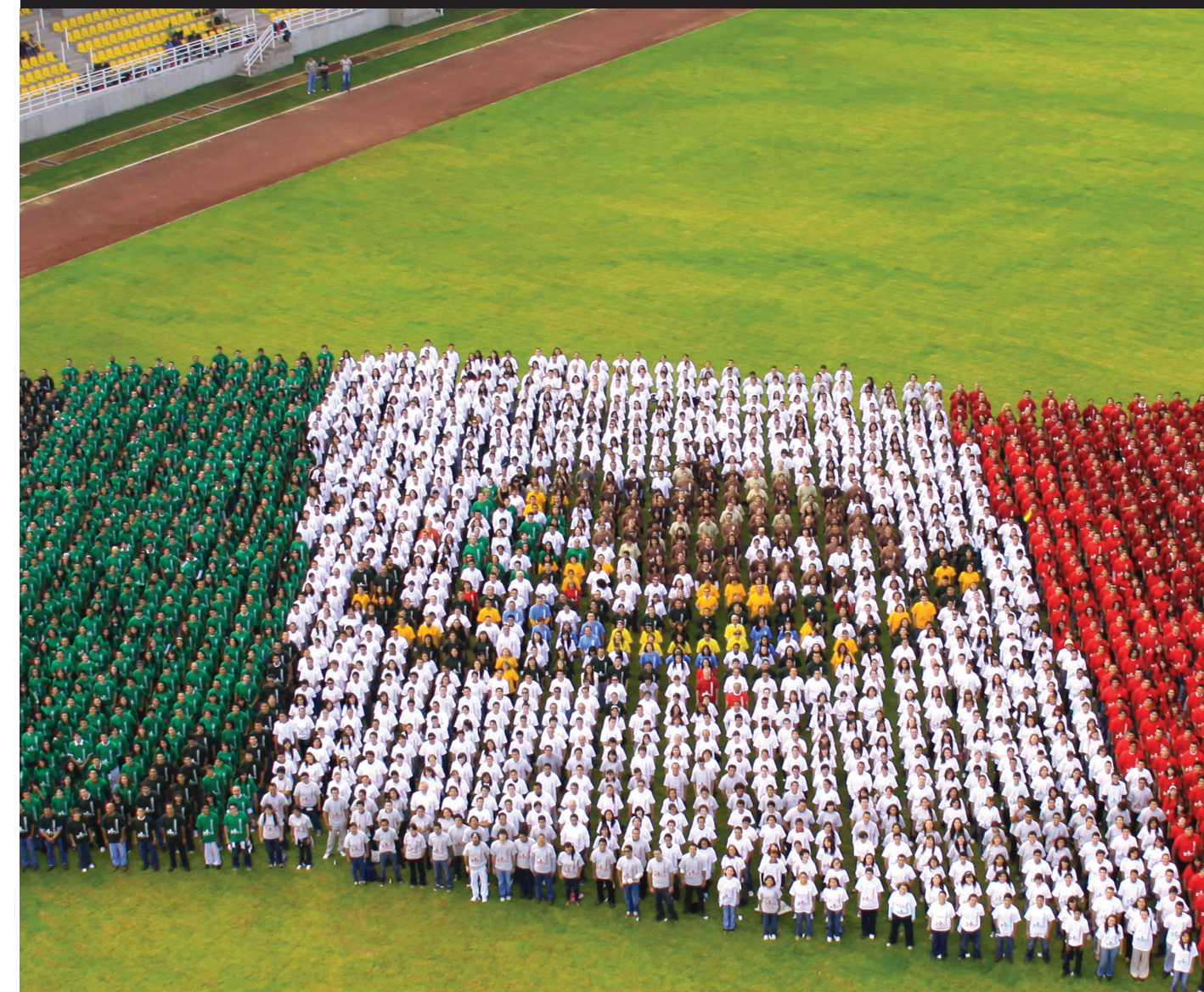